\title{
Separation/Analysis of Congo Red by Using Poly (Ionic Liquid) Immobilized Magnetic Nanoparticles Magnetic Solid Phase Extraction Coupled with Fluorescence Spectrophotometry
}

\author{
Almojtaba Abd Alkhalig Ahmed Bakheet ${ }^{1,2, *}$, Xiashi Zhu ${ }^{1}$ \\ ${ }^{1}$ College of Chemistry \& Chemical Engineering, Yangzhou University, Yangzhou, China \\ ${ }^{2}$ Department of Family Sciences, Faculty of Education, University of Khartoum, Khartoum, Sudan \\ Email address: \\ mugtabaahmed32@yahoo.com (A. A. A. A. Bakheet), moj76@uofk.edu (A. A. A. A. Bakheet) \\ ${ }^{*}$ Corresponding author
}

\section{To cite this article:}

Almojtaba Abd Alkhalig Ahmed Bakheet, Xiashi Zhu. Separation/Analysis of Congo Red by Using Poly (Ionic Liquid) Immobilized Magnetic Nanoparticles Magnetic Solid Phase Extraction Coupled with Fluorescence Spectrophotometry. Science Journal of Analytical Chemistry. Vol. 5, No. 6, 2017, pp. 113-118. doi: 10.11648/j.sjac.20170506.17

Received: November 15, 2017; Accepted: November 25, 2017; Published: January 2, 2018

\begin{abstract}
Magnetic solid phase extraction (MSPE) accompanied with fluorescence spectrophotometry using Poly (ionic liquid) immobilized magnetic nanoparticles (PIL-MNPs) as sorbent was introduced for Congo red analysis in food. Poly (1-vinyl-3-butylimidazolium) bromide immobilized (MNPs) were prepared through co-polymerization of 1-vinyl-3-hexylimidazolium-based ionic liquid and vinyl-modified magnetic particles. Some of different types of parameters, such as $\mathrm{pH}$ value, adsorption temperature and time, sample volume, eluent type, were studied. Under the optimum conditions, the preconcentration factor for AR was 27. The linear range, detection limit (DL), correlation coefficient (R) and relative standard deviation (RSD) were found to be $0.10-9.00 \mu \mathrm{g} / \mathrm{mL}, 5.2 \mu \mathrm{g} / \mathrm{L}, 0.9987$ and $3.10 \%(\mathrm{n}=3, \mathrm{c}=4.00 \mu \mathrm{g} / \mathrm{mL})$. This method had been successfully applied to the separation / analysis of Congo red in real samples.
\end{abstract}

Keywords: Congo Red, Poly (Ionic Liquid) Magnetic Nanoparticles, Magnetic Solid-Phase Extraction, Fluorescence Spectrophotometry

\section{Introduction}

Congo red (dipheny 1-4, 4'-(azo-2-) 2-1-amino naphthalene-4-sodium sulfonate, $\mathrm{CR}$ ) is a kind of benzidine anionic dyes. It is commonly used as biological stain and chemical indicator. $\mathrm{CR}$ is not edible pigment which is not allowed to add into food because it has good stability and can not be biodegradable which causes serious harm to aquatic organisms and food web [1]. CR causes also the human body dyspnea, emesis, diarrhea and nausea and its metabolites benzidine has toxic and carcinogenic to the human body [2]. Therefore, it is very important to establish an accurate and sensitive method for determination of congo red in drinking water and food.

UV-vis spectrophotometry was used in literatures for CR determination in high concentration of CR [3]. However, direct determination is difficult owing to low concentration of $\mathrm{CR}$ in samples. Therefore, it is necessary to develop a more accurate procedure for separation/preconcenrtation of $\mathrm{CR}$ in trace amounts. The definition of (MSPE) was that it is a process depends on using magnetic absorbents for separation and pre-concentration of various analytes from high amounts of sample. The magnetic absorbent was mixed with sample and the analyte was adsorbed by magnetic sorbent particles (M-SPs). Analyte-M-SPs were separated from the sample solution through an external magnetic field, after elution with the perfect eluent. Nowadays, MSPE absorbent is exactly focused on $\mathrm{Fe}_{3} \mathrm{O}_{4}$ nanoparticles (NPs) with special functional groups changed to measure the amount of the aimed analytes. various polymers were used to modify $\mathrm{Fe}_{3} \mathrm{O}_{4} \mathrm{NPs}$ [4], [5], Silica functionalized magnetic agents $\left(\mathrm{Fe}_{3} \mathrm{O}_{4} @ \mathrm{SiO}_{2}\right)$ was commonly used to extract the lower concentration of inorganic ions due to their good proprieties like easy surface 
modification and control of inter particle interactions [6], [7]. C18-functionalized $\mathrm{Fe}_{3} \mathrm{O}_{4} @ \mathrm{SiO}_{2} \quad$ core-shell magnetic nanoparticles were used for and determination of phthalic acid esters in Chinese herb preparations [8]. Silica-coated magnetite particles functionalized with diphenyl groups have also been used to determine the PAHs in urine from smokers and non-smokers [9].

Ionic liquids (ILs) are a type of organic salts that had special physio-chemical properties like fair stability and hydrophobic properties [10], [11], ionic liquids coated MNPs were used as adsorbent in separation of aromatic hydrocarbons in water [12], as an example $\mathrm{Fe}_{3} \mathrm{O}_{4} @ \mathrm{SiO}_{2} @$ ILs was used to separate $\mathrm{Cd}^{2+}$ from water [13], and also was used as sorbent for separation of flavonoids [14].

In a different work, ionic liquid-modified materials were applied by using the immobilized1-hexylimidazole onto magnetic agents, where is a better extraction efficiency of some sulfonylurea herbicides were obtained [15]. IL-modified magnetic polymer based on $\mathrm{Fe}_{3} \mathrm{O}_{4}$ and 1-butyl-3-methylimidazolium IL, was used as magnetic adsorbent for the screening of two sulfonamides in urine [16].

Poly ionic liquids (PILs) has many properties and applications such as materials science, separation and analytical chemistry, [17], [18] Rapid advances in physio-chemical proprieties of (PILs), wide surface area and available adsorption sites. was developed novel poly electrolytes which were very important in research and introduced substances in future studies in different fields [19], [20].

In separations science field, PILs was applied in SFE and chromatography. Recently scientists composed stationary phases depend on imidazolium-derived PILs to be used in gas chromatography, showing fair reliability.

It was reported that magnetic materials coated with PIL proved to be a more efficient catalyst compared to the immobilization of conventional IL [21].

A few previous studies were used 1-ally-3-vinylimidazolium chloride and, silica-coated MNPs and poly (1-vinyl-3-butylimidazolium) bromide as magnetic sorbent. Using the current polymer poly (1-vinyl-3-butylimidazolium) enabled the fabrication of graphene-containing polyelectrolyte membranes [22], $\mathrm{Fe}_{3} \mathrm{O}_{4} @ \mathrm{SiO}_{2} @ \mathrm{PIL}$ was applied for separation of organophosphorus pesticides in tea samples [23], Thus, it wasn't been reported to separate Congo red by $\mathrm{Fe}_{3} \mathrm{O}_{4} @ \mathrm{SiO}_{2} @$ PILs.

In this study, MSPE sorbents, $\mathrm{Fe}_{3} \mathrm{O}_{4} @ \mathrm{SiO}_{2} @ \mathrm{PILs}$ were synthesized. A magnetic adsorbent modified with PIL was reported and applied for separation of high samples concentration in a few minutes. The $\mathrm{Fe}_{3} \mathrm{O}_{4} @ \mathrm{SiO}_{2} @ \mathrm{PIL}$ NPs was used for 10 times. In comparison with different references [24], reusability of $\mathrm{Fe}_{3} \mathrm{O}_{4} @ \mathrm{SiO}_{2} @ \mathrm{PIL}$ NPs was satisfactory. In addition to this, a novel method of MSPE coupled with fluorescence spectrophotometry for separation of Congo red from food samples was introduced.

\section{Experimental Section}

\subsection{Materials}

Chemicals were offered through reagent grade, others mentioned. Standards solutions were purchased from Shanghai Chemical Reagent Corporation, (China).

1-Bromohexane and tetraethyl orthosilicate (TEOS) were bought from Chemical Reagent Co., Ltd.

\subsection{Equipment}

Centrifuge (Anke Scientific Instrument Factory Shanghai), timing multifunctional oscillator (Guohua Co., Ltd., China), digital constant temperature water-bath (Guohua Co., Ltd., China).

A F-4500 spectrophotometer (Hitachi, Japan) was used for all the fluorescence measurement, with excitation and emission slits at $5.0 \mathrm{~nm}, \lambda \mathrm{ex}=330 \mathrm{~nm}$ and $1-\mathrm{cm}$ quartz cell.

\subsection{Preparation of Poly (Ionic Liquid) Functionalized Magnetic Nanoparticles ( $\left.\mathrm{Fe}_{3} \mathrm{O}_{4} @ \mathrm{SiO}_{2} @ P I L s\right)$}

\subsubsection{Preparation of IL Monomer}

1-vinyl-3-hexylimidazolium bromide ([VHim] Br) IL monomer had prepared through the reaction of $0.1 \mathrm{~mol}$ of 1-vinylimidazole and $0.1 \mathrm{~mol}$ of 1-bromohexane in $20 \mathrm{~mL}$ of 2-propanol at $90^{\circ} \mathrm{C}$ for $24 \mathrm{~h}$ with stirring. After decreasing temperature to $25^{\circ} \mathrm{C}$ [25].

\subsubsection{Preparation of $\mathrm{Fe}_{3} \mathrm{O}_{4} @ \mathrm{SiO}_{2}$ Magnetic Nanoparticles}

Magnetic $\mathrm{Fe}_{3} \mathrm{O}_{4}$ nanoparticles were prepared by chemical co-precipitation method [26]. First, $\mathrm{FeCl}_{3}(3.30 \mathrm{~g})$ was dissolved in deionized water $(80 \mathrm{~mL})$ followed by addition of polyethylene glycol $(40 \mathrm{~mL}, 10 \%, \mathrm{w} / \mathrm{w})$ and of $\left(\mathrm{NH}_{4}\right)_{2} \mathrm{Fe}$ $\left(\mathrm{SO}_{4}\right)_{2}(4.23 \mathrm{~g})$ added in water solution under stirring. Then ammonium hydroxide $(8 \mathrm{~mL}, 26.5 \%$, w/w) was added rapidly under vigorous stirring. The resultant solution was stirred $\left(1000 \mathrm{r} \mathrm{min}^{-1}\right)$ at $80^{\circ} \mathrm{C}$ for $60 \mathrm{~min}$. After cooling to room temperature, the obtained $\mathrm{Fe}_{3} \mathrm{O}_{4}$ precipitate was collected by an external magnetic field, washed with deionized water five times and dried at $60^{\circ} \mathrm{C}$ for $12 \mathrm{~h}$ in vacuum.

Magnetic $\mathrm{Fe}_{3} \mathrm{O}_{4} @ \mathrm{SiO}_{2}$ nanoparticles were prepared through hydrolysis of tetraethyl orthosilicate TEOS through sol-gel process as detailed [27]. $\mathrm{Fe}_{3} \mathrm{O}_{4}(1.0 \mathrm{~g})$ were dissolved in $200 \mathrm{~mL}$ ethanol and $50 \mathrm{~mL}$ deionized water by sonication for $15 \mathrm{~min}$, and then $4 \mathrm{~mL}$ ammonium hydroxide and $6 \mathrm{~mL}$ TEOS were added sequentially. The mixture was reacted for $6 \mathrm{~h}$ at $60^{\circ} \mathrm{C}$ under a continuous stirring. The resultant product was collected by an external magnetic field, and rinsed with deionized water and ethanol for six times thoroughly, and dried in vacuum to obtain $\mathrm{Fe}_{3} \mathrm{O}_{4} @ \mathrm{SiO}_{2}$.

\subsubsection{Preparation of $\mathrm{Fe}_{3} \mathrm{O}_{4} @ \mathrm{SiO}_{2} @ P I L$ Magnetic Nanoparticles}

Vinyltriethoxysilane-modified $\mathrm{Fe}_{3} \mathrm{O}_{4} @ \mathrm{SiO}_{2}$ nanoparticles $\left(\mathrm{Fe}_{3} \mathrm{O}_{4} @ \mathrm{SiO}_{2} @\right.$ VTES) were prepared through reacting $\mathrm{Fe}_{3} \mathrm{O}_{4} @ \mathrm{SiO}_{2}$ with $10 \mathrm{mmol}$ of vinyltriethoxysilane by using tri-ethylamine at $110^{\circ} \mathrm{C}$ for $24 \mathrm{~h}$. Then washed and dried under vacuum for $24 \mathrm{~h}$ at $40^{\circ} \mathrm{C}$.

PIL was immobilized on magnetic nanoparticles surface by the free radical copolymerization of 1-vinyl-3-hexylimidazolium bromide [VHim] $\mathrm{Br}$ and $\mathrm{Fe}_{3} \mathrm{O}_{4} @ \mathrm{SiO}_{2}$ in chloroform using 2, 2'-Azobis-(2-methylpropionitrile) AIBN as an initiator. Typically, $8 \mathrm{~g}$ of $\mathrm{Fe}_{3} \mathrm{O}_{4} @ \mathrm{SiO}_{2} @$ VTES, $4 \mathrm{~g}$ of [VHim] $\mathrm{Br}$ and $0.04 \mathrm{~g}$ of 
AIBN were added to $100 \mathrm{~mL}$ of chloroform and mechanically stirred for $1 \mathrm{~h}$ at room temperature. The mixture was heated to $75^{\circ} \mathrm{C}$ to remove chloroform slowly and allowed to react at $90^{\circ} \mathrm{C}$ for $2 \mathrm{~h}$. Finally, the obtained PIL-MNPs, namely, $\mathrm{Fe}_{3} \mathrm{O}_{4} @ \mathrm{SiO}_{2} @ \mathrm{PIL}$ were collected by magnetic separation and washed three times with chloroform, two times with methanol and water, and dried under vacuum at $40^{\circ} \mathrm{C}$ for $5 \mathrm{~h}$.

\subsection{Procedure for Extraction}

In a 10.0mL test tube, $0.05 \mathrm{~g} \mathrm{Fe}_{3} \mathrm{O}_{4} @ \mathrm{SiO}_{2} @ \mathrm{PIL}$-MNPs, $0.3 \mathrm{~mL} 1 \%, 2.0 \mathrm{~mL}$ of buffer solution $(\mathrm{pH}=7.0)$ and adequate Congo red standard or sample solution were added; the solution was diluted to the mark with distilled water. Then fluorescence spectra were recorded in the range of 300-700 $\mathrm{nm}$ upon excitation at $350 \mathrm{~nm}$.

\subsection{Sample Preparation}

$1.0 \mathrm{~mL}$ of beverages samples were weighed in a small beaker. The liquid was dissolved in $30 \mathrm{~mL}$ distilled water at $60^{\circ} \mathrm{C}$ ultrasonically extracted for $30 \mathrm{~min}$ and then filtrated to obtain supernatant. The solution was poured in $250 \mathrm{~mL}$ flask then dissolved with distilled water.

$1.0 \mathrm{~mL}$ city water sample was transferred into a $100 \mathrm{~mL}$ volumetric flask. The sample solution was put in dark at $4^{\circ} \mathrm{C}$.

\subsection{Elution Method}

Desorption was examined by adding $4.0 \mathrm{~mL}$ of desorption eluent ethanol to the Congo red adsorbent material $\left(\mathrm{Fe}_{3} \mathrm{O}_{4} @ \mathrm{SiO}_{2} @\right.$ PILs MNPs) as $(0.1 \mathrm{~g})$. After ultrasonic treating for $15 \mathrm{~min}$ at $30^{\circ} \mathrm{C}, \mathrm{Fe}_{3} \mathrm{O}_{4} @ \mathrm{SiO}_{2}$ PILs was collected by magnetic decantation and the concentration of Congo red in the supernatant was measured on fluorescence spectrophotometer.

\section{Results and Discussion}

\subsection{Characterization of $\mathrm{Fe}_{3} \mathrm{O}_{4} @ \mathrm{SiO}_{2} @ \mathrm{PIL}$}

\subsubsection{Characterization by FTIR}

The infra red spectrum of $\mathrm{Fe}_{3} \mathrm{O}_{4}$ (curve a), $\mathrm{Fe}_{3} \mathrm{O}_{4} @ \mathrm{SiO}_{2}$ (curve b) and PIL (curve c) were illustrated in Figure 1. Compared curves of $\mathrm{a}$ and $\mathrm{b}$, the absorbance at $579 \mathrm{~cm}^{-1}$ was due the propriety of Fe-O-Fe, then the peak at 1000-1200 $\mathrm{cm}^{-1}$ meight be attributed to the silanol groups ( $\mathrm{Si}-\mathrm{O}-\mathrm{H}$, $\mathrm{Si}-\mathrm{O}-\mathrm{Si}$ ) of silica. FTIR spectra of PIL, the peak at $1575 \mathrm{~cm}^{-1}$ was significantly reduced which due $\mathrm{N}-\mathrm{H}$ stretching vibration; and the transmittance at wave numbers 2850 and $2920 \mathrm{~cm}^{-1}$ were due to $\mathrm{C}-\mathrm{H}$ stretching vibration in the PILs [15], which showed that PILs were well immobilized on the surface magnetic nanoparticles.

\subsubsection{Characterization by XRD}

Figure 2 illustrated the XRD spectra of the $\mathrm{Fe}_{3} \mathrm{O}_{4} @ \mathrm{SiO}_{2} @$ PILMNPs. The six clear peaks was appeared at $2 \theta$ of $31.2^{\circ}, 37.3^{\circ}, 45.3^{\circ}, 53.1^{\circ}, 56.4^{\circ}$, and $67.4^{\circ}$. The spectra of $\mathrm{Fe}_{3} \mathrm{O}_{4} @ \mathrm{SiO}_{2} @ \mathrm{PIL}$ was same as $\mathrm{Fe}_{3} \mathrm{O}_{4}$, which proved that the crystal shape of $\mathrm{Fe}_{3} \mathrm{O}_{4}$ particles were not altered through modifying of poly ionic liquid.

\subsection{Thermo-Gravimetric Analysis (TGA)}

(TGA) was applied, and the heating rate was $5^{\circ} \mathrm{C} \min ^{-1}$ and all times between $25-800^{\circ} \mathrm{C}$. Figure 3 showed the TGA of $\mathrm{Fe}_{3} \mathrm{O}_{4} @ \mathrm{SiO}_{2}$ (curve a) and $\mathrm{Fe}_{3} \mathrm{O}_{4} @ \mathrm{SiO}_{2} @ \mathrm{PIL}$ (curve b). The figure illustrates a weight loss of $30 \%$ at $250{ }^{\circ} \mathrm{C}$ due to the water content. Compared curve $\mathrm{a}$ and $\mathrm{b}$, more decreasing of weight $4.6 \%$ appeared which was shown in range of 300 to $350^{\circ} \mathrm{C}$, and attributed to the coating of PILs.

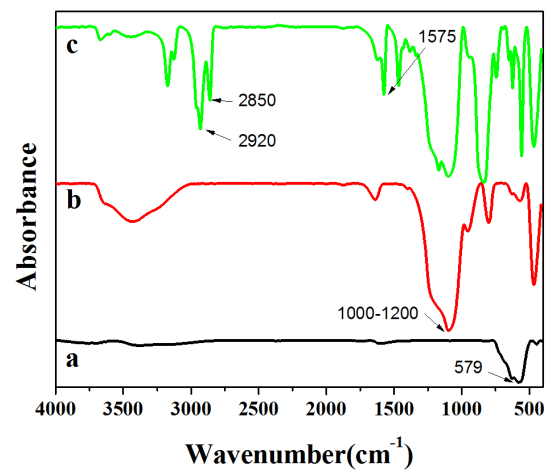

Figure 1.FT-IR spectra of $\mathrm{Fe}_{3} \mathrm{O}_{4} @ \mathrm{SiO}_{2}(\mathrm{~A}), \mathrm{PIL}(\mathrm{B})$ and $\mathrm{Fe}_{3} \mathrm{O}_{4} @ \mathrm{SiO}_{2} @ P I L$ (C).

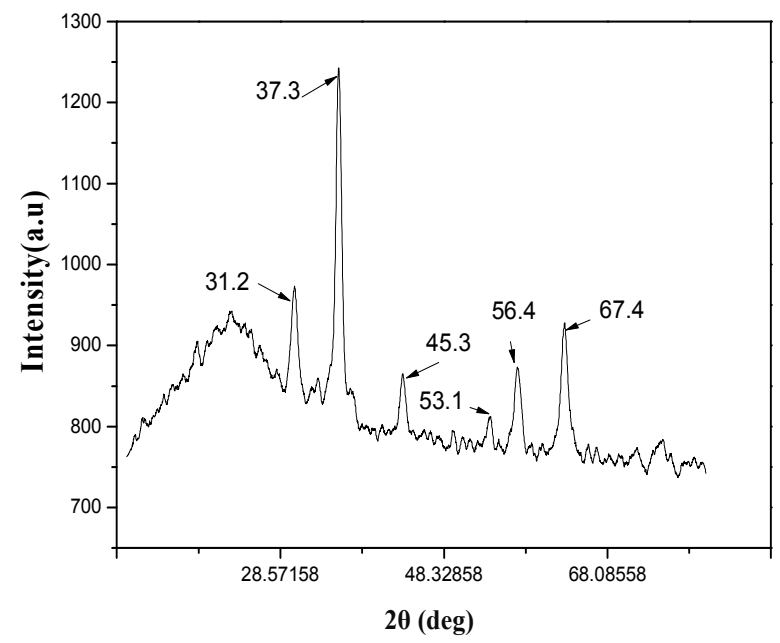

Figure 2.XRD spectra of the $\mathrm{Fe}_{3} \mathrm{O}_{4} @ \mathrm{SiO}_{2} @ P I L M N P s$.

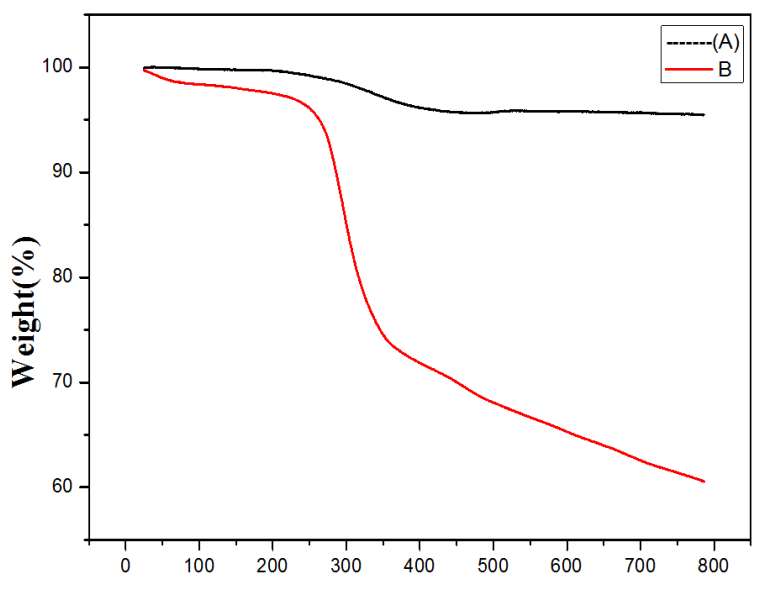

Temperature $/{ }^{\circ} \mathrm{C}$

Figure 3.TGA curves of (A) $\mathrm{Fe}_{3} \mathrm{O}_{4} @ \mathrm{SiO}_{2}$ and $(\mathrm{B}) \mathrm{Fe}_{3} \mathrm{O}_{4} @ \mathrm{SiO}_{2} @ P I L$. 


\subsection{Adsorption Process}

Many factors which affected the extraction operation of Congo red like $\mathrm{pH}$, temperature and solution volume were studied.

\subsection{1. $\mathrm{pH}$ Value}

As shown in (Figure 4A), the extraction efficiency of Congo red was varied with the $\mathrm{pH}$ value. It could be concluded that the extraction efficiency of Congo red on PIL MNPs was above $60.0 \%$. It reached the highest value $89.8 \%$ when $\mathrm{pH}$ was 7.0 .

\subsubsection{Adsorption Temperature}

The extraction efficiency of Congo red on PIL MNPs at various temperatures $\left(5-50^{\circ} \mathrm{C}\right)$ were investigated (Figure 4B). The efficiency of extraction of Congo red on $\mathrm{Fe}_{3} \mathrm{O}_{4} @ \mathrm{SiO}_{2} @$ PILwas higher and always above 70\% from $5^{\circ} \mathrm{C}$ to $20^{\circ} \mathrm{C}$ and it was above $83 \%$ at $25^{\circ} \mathrm{C}$ then it decreased. The experiment was done at room temperature.

\subsubsection{Extraction Time}

The effect of extraction time on extraction efficiency showed that the adsorption process was increased from 5 to 15 min and was finished in $15.0 \mathrm{~min}$, after that adsorption efficiency remained almost static (95.3.\%). $15.0 \mathrm{~min}$ as the adsorption time for Congo red was selected (Figure 4C).

\subsubsection{Sample Volume}

The extraction efficiency of Congo red was varied with the increased sample amount. The volume of Congo red was selected at $50.0 \mu \mathrm{g}$ and amount of sample increased from $10.0 \mathrm{~mL}$ to $100.0 \mathrm{~mL}$. The extraction efficiency of Congo red was higher than $83 \%$ from 10.0 to $80.0 \mathrm{~mL}$ and remain steady, and then it decreased $81.13 \%$ when sample volume was $100.0 \mathrm{~mL}$. Thus the largest sample amount allowed was $80.0 \mathrm{~mL}$ (Figure 4D).
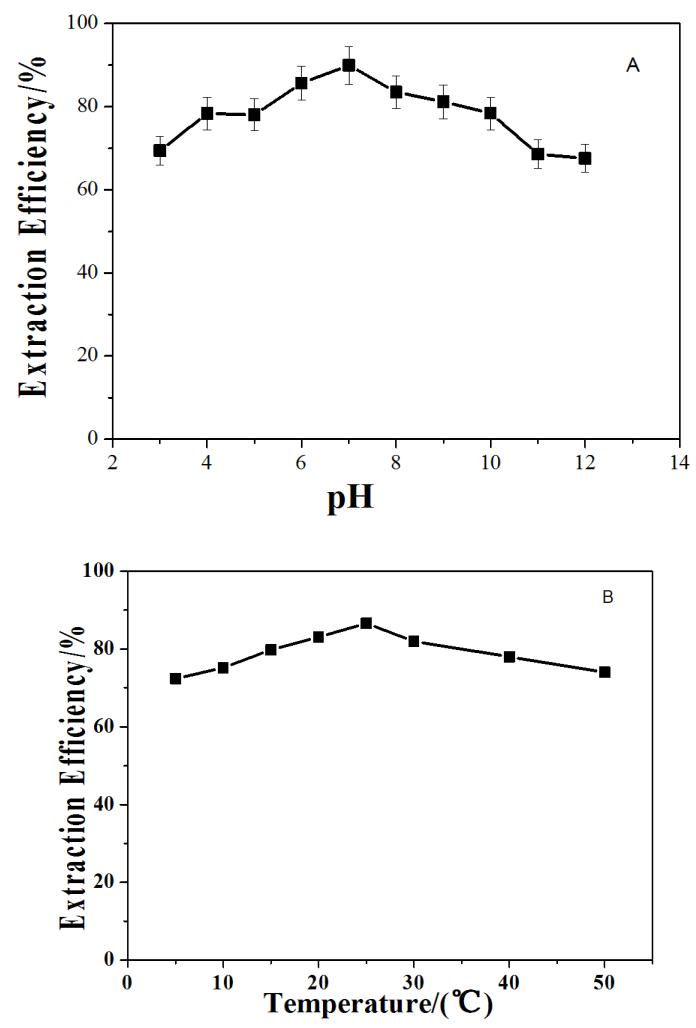
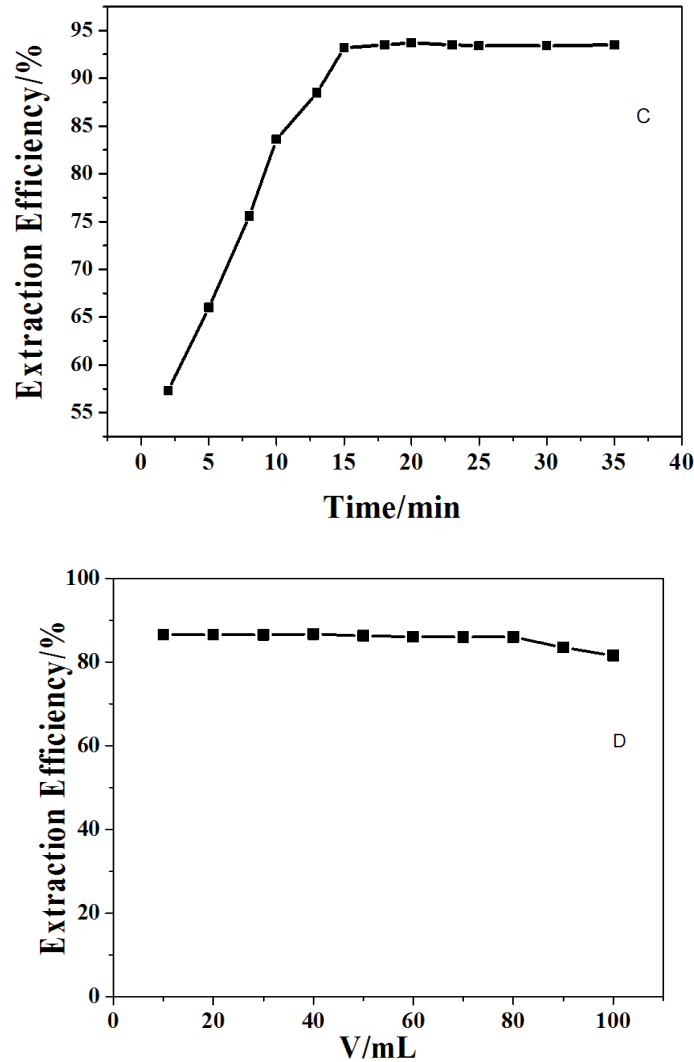

Figure 4. (A) Effect of $p H$ on extraction efficiency at temperature $25^{\circ} \mathrm{C}$, a sample volume of $10.0 \mathrm{~mL}$, and a preconcentration time of 15 minutes. (B) Effect of temperature on extraction efficiency pH 7.0, sample volume of $10.0 \mathrm{~mL}$, and a preconcentration time of 15 minutes. (C) Effect of adsorption time on extraction efficiency at $p H 7.0$, temperature $25^{\circ} \mathrm{C}$, a sample volume of $10.0 \mathrm{~mL}$. (D) Effect of sample volume on extraction efficiency at pH 7.0, temperature $25^{\circ} \mathrm{C}$ and a preconcentration time of 15 minutes.

\subsubsection{Capacity of Adsorption}

The capacity of adsorption is known as the highest volume of Congo red adsorbed per gram of $\mathrm{Fe}_{3} \mathrm{O}_{4} @ \mathrm{SiO}_{2} @$ PIL MNPs. The adsorption capacity of Congo red on PIL MNPs was studied (Figure 5). When the concentration of Congo red was $70.0 \mu \mathrm{g} \mathrm{mL}{ }^{-1}$, the adsorption of Congo red reached the maximum. The adsorption capacity for $\mathrm{Fe}_{3} \mathrm{O}_{4} @ \mathrm{SiO}_{2} @ \mathrm{PIL}$ is calculated as $10.45 \mathrm{mg} \mathrm{g}^{-1}$.

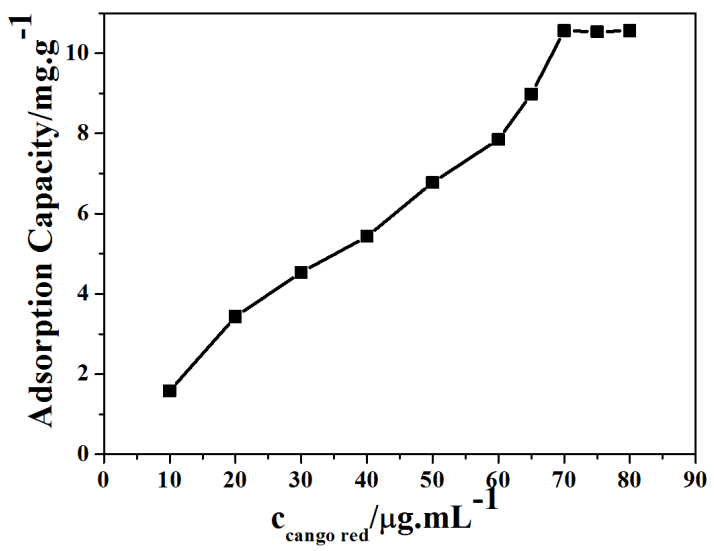

Figure 5. Adsorption capacity. 


\subsection{Elution Process}

\subsubsection{Eluent Type}

Selection of eluent type is of vital importance which determines the final extraction efficiency. Various eluents were studied. The order of elution efficiency was ethanol $>$ methanol $>$ cetyltrimethyl ammonium bromide $(\mathrm{CTAB})>$ sodium dodecyl sulfonate $(\mathrm{SDS})>\mathrm{NaOH}\left(0.1 \mathrm{~mol} . \mathrm{L}^{-1}\right)>\mathrm{HCl}$ $\left(0.1 \mathrm{~mol} . \mathrm{L}^{-1}\right)$. So ethanol was selected.

\subsubsection{Eluent Volume}

Effect of ethanol volume on the elution efficiency of Congo red, was directly studied. The results showed that it was (over $93 \%$ ) when ethanol was over than $3.0 \mathrm{~mL}$. The optimum volume of ethanol was selected at $3.0 \mathrm{~mL}$.

\subsubsection{Elution Time}

The elution process was finished in $15.0 \mathrm{~min}$, elution efficiency did not changed until it reached $94.42 \%$ thereafter. Elution time of $15.0 \mathrm{~min}$ for Congo red was adopted.

\subsubsection{Elution Temperature}

Elution efficiency of Congo red at various temperatures (5$60^{\circ} \mathrm{C}$ ) was observed, which was increased with increasing temperature until $30^{\circ} \mathrm{C}$. Then it was higher than $84 \%$ and decreased from 30 to $60^{\circ} \mathrm{C}$. Therefore, $25^{\circ} \mathrm{C}$ was selected as elution temperature.

\subsection{The Reusabilityof $\mathrm{Fe}_{3} \mathrm{O}_{4} @ \mathrm{SiO}_{2} @ P I L$}

The $\mathrm{Fe}_{3} \mathrm{O}_{4} @ \mathrm{SiO}_{2} @$ PIL were washed with $2.0 \mathrm{~mL}$ of ethanol tow times after each MSPE procedure, and assembled with PILs. The reusability of $\mathrm{Fe}_{3} \mathrm{O}_{4} @ \mathrm{SiO}_{2} @$ PILwas applied via efficiency of adsorption and elution. (Figure 6). the $\mathrm{Fe}_{3} \mathrm{O}_{4} @ \mathrm{SiO}_{2} @ \mathrm{PIL}$ material could be reused nine times with efficiency of adsorption higher than $83 \%$ to Congo red.

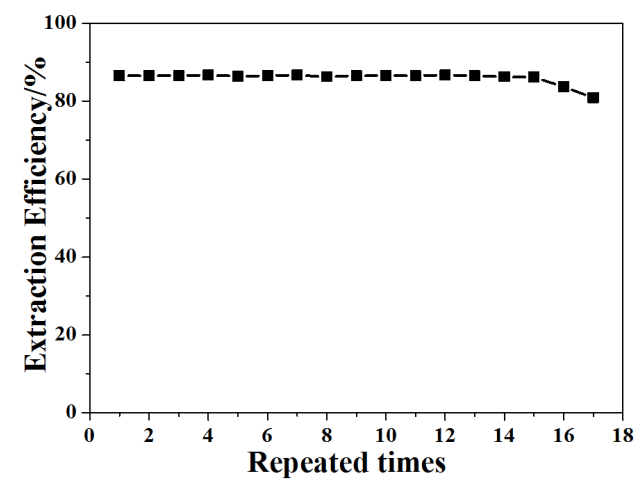

\subsection{Interferents Effect}

The effect of interferents which food samples may contain on separation of Congo red in the availability of interferents was investigated. the tolerance limit for different interferents was as follow, for interferents $\mathrm{Zn}^{2+}, \mathrm{Ca}^{2+}, \mathrm{Mg}^{2+}$, the tolerance ratio was 102 . for interferent $\mathrm{Cu}^{2+}$, tebuconazole ratio was 53, for interferent Triadimefon, 2-nitrophenol ratio was 35 and it was 15 for $\mathrm{Fe}^{3+}, \mathrm{NO}_{3}{ }^{-}, \mathrm{SO}_{4}{ }^{2-}$, Carbendazim, benomyl, acetamiprid, 4-Nitrophenol, phenol. The results showed that most of the foreign substances had no interference with Congo red.

\subsection{Analytical Application}

Under optimum conditions described above, the preconcentration factor for AR was 27. The linear range, detection limit (DL), correlation coefficient (R) and relative standard deviation (RSD) were found to be $0.10-9.00 \mu \mathrm{g} / \mathrm{mL}$, $5.2 \mu \mathrm{g} / \mathrm{L}, 0.9987$ and $3.10 \%(\mathrm{n}=3, \mathrm{c}=4.00 \mu \mathrm{g} / \mathrm{mL})$.

\subsection{Analysis of Sample}

This method was introduced to separate the amount of Congo red in certain types of beverages and city water. To further verify for the viability of the method, recovery experiments were carried out for the spiked samples ranged from $98.0 \%$ to $107.0 \%$, the results were satisfactory (Table $1)$.

Table 1. The analysis results of samples.

\begin{tabular}{llll}
\hline Samples & Added $\left(\boldsymbol{\mu g} \mathbf{~ m L}^{-\mathbf{1}}\right)$ & Found $\left(\boldsymbol{\mu g} \mathbf{~ m L}^{-\mathbf{1}}\right)$ & Recovery $(\%)$ \\
\hline \multirow{4}{*}{ Beverages } & 0.00 & ND & - \\
& 0.50 & 0.49 & 98.0 \\
& 2.00 & 2.01 & 100.5 \\
& 4.00 & 4.13 & 103.2 \\
& 0.00 & 0.74 & - \\
City Water & 0.50 & 1.25 & 102.0 \\
& 2.00 & 2.88 & 107.0 \\
& 4.00 & 4.73 & 99.8 \\
\hline
\end{tabular}

\subsection{Comparison with Other Methods}

Table 2 listed the linear range and the limit of detection for separation of Congo red in real samples obtained by the reported methods. Compared with other reported methods, the method adopted in the present work is obviously had a satisfactory linear range and limit of detection.

Figure 6. Effect of reuse of PIL MNPs in extraction and elution.

Table 2. Comparison of analytical performance of this method with other methods for determining congo red.

\begin{tabular}{|c|c|c|c|c|c|c|c|}
\hline Adsorbent & Method & $\mathrm{pH}$ & Time & $\mathrm{T}\left({ }^{\circ} \mathrm{C}\right)$ & $Q_{m}\left(\mathrm{mg} \mathrm{g}^{-1}\right)$ & Reusability & Ref. \\
\hline Ni-ZnS-NP-AC & UV-Vis & 3 & $22 \mathrm{~min}$ & 25 & 285.7 & 1 & {$[28]$} \\
\hline Activating natural bentonite & UV-Vis & 1 & $24 \mathrm{~h}$ & 30 & 7.0 & l & [29] \\
\hline GWAC & UV-Vis & 6.95 & $3 \mathrm{~h}$ & 25 & 455 & l & {$[30]$} \\
\hline $\mathrm{Fe}_{3} \mathrm{O}_{4} @ \mathrm{SiO}_{2} @ \mathrm{PIL}$ & MSPE- FL & 7 & $15 \mathrm{~min}$ & 25 & 5.24 & At least 17 times & This work \\
\hline
\end{tabular}




\section{Conclusion}

In this work, $\mathrm{Fe}_{3} \mathrm{O}_{4} @ \mathrm{SiO}_{2} @$ PIL MNPs was synthesized as magnetic solid phase extraction adsorbent coupled with fluorescence spectrophotometry to separate Congo red in food samples. PILs as possible environmentally friendly solvent can obtain good extraction efficiency. The magnetic separation greatly improved the separation rate and reduced the analysis time. In conclusion, poly ionic liquids immobilized MNPs could be considered as a promising alternative for the extraction of Congo red. This introduced method for the separation of Congo red from real samples was proved to be satisfactory.

\section{Acknowledgements}

Authors acknowledge financial supply of National Natural Science Foundation of China $(21155001,21375117)$ and the Priority Academic Program Development of Jiangsu Higher Education Institutions.

\section{References}

[1] C. Srilakshmi, R. Saraf. Micropor. Mesopor. Mat. 219, 134 (2016).

[2] G. A. Sayg111. J. Mol. Liq. 211, 515 (2015).

[3] L. N. Jin, X. Y. Qian, J. G. Wang, H. S. Aslan, M. D. Dong. J. Colloid Interf. Sci., 453, 27 (2015).

[4] X. S. Li, L. D. Xu, G. T. Zhu, B. F. Yuan, Y. Q. Feng, Analyst 137 (2012) 959-967.

[5] H. M. Chen, C. H. Deng, X. M. Zhang, Chem Int Ed 49 (2010) 607-611.

[6] M. C. Deng, C. Jiang, L. Jia, Anal. Chim. Acta 771 (2013) 3136.

[7] M. M. Abolghasemi, V. Yousefi, M. Piryaei, Microchim Acta 182 (13) (2015) 2155- 2164.

[8] B. Guo, S. Ji, F. Zhang, B. Yang, J. P. Gu, X. M. Liang, J. Pharmaceut Biomed 100 (2014) 365-368

[9] F. Bianchi, V. Chiesi, F. Casoli, P. Luches, L. Nasi, M. Careri, A. Mangia. J Chromatogr A 1231 (2012) 8-15.

[10] F. Galan-Cano, M. C. Alcudia-Leon, R. Lucena, S. Cardenas, M. Valcarcel, J. Chromatogr. A 1300 (2013) 134-140.
[11] S. A. Nizar, F. B. M. Suah, J. Fluoresc (2016) 1-5.

[12] H. He, D. H. Yuan, Z. Q. Gao, D. L. Xiao, H. He, H. Dai, J. Peng, N. V. Li, J Chromatogr A1324 (2014) 78-85.

[13] X. F. Liu, X. Lu, Y. Huang, C. W. Liu, S. L. Zhao, Talanta 119 (2014) 341-347.

[14] D. D. Ge, H. Kee Lee, J. Chromatogr. A 1229 (2012) 1-5.

[15] Z. Y. He, D. H. Liu, Z. Q. Zhou, P. J. Sep. Sci. 00 (2013) 1-8.

[16] H. Y. Yan, M. M. Gao, C. Yang, M. D. Qiu, Anal. Bioanal. Chem. 406 (2014) 2669-2677.

[17] L. Ruiz-Aceituno, M. L. Sanz, L. Ramos, Trend Anal. Chem. 43 (2013) 121-145.

[18] M. J. Trujillo-Rodriguez, P. Rocío-Bautista, V. Pino, A. M. Afonso, Trends Anal. Chem. 51 (2013) 87-106.

[19] L. J. He, K. G. Zhang, C. J. Wang, X. L. Luo, S. S. Zhang, J. Chromatogr. A 1218 (2011) 3595-3600.

[20] X. Y. Zheng, L. J. He, Y. J. Duan, X. M. Jiang, G. Q. Xiang, W. J. Zhao, S. S. Zhang, J. Chromatogr. A 1358 (2014) 39-45.

[21] A. Pourjavadi, S. H. Hosseini, S. A. Aghayee Meibody, S. T. Hosseini, C. R. Chim. 16 (2013) 906-911.

[22] B. Kirchner, B. Clare, Ionic Liquids, first ed., Springer-Verlag, Berlin, Heidelberg (2009).

[23] N. Deng, M. Li, L. J. Zhao, C. F. Lu, S. L. Rooy, I. M. Warner, J Hazard Mater 192 (2011) 1350-1357.

[24] Y. J. Meng, J. L. Anderson, J. Chromatogr. A 1217 (2010) $6143-6152$.

[25] Cheng Q., Qu F., Li N. B., Luo H. Q, Anal Chim Acta 715 (2012) 113-119.

[26] Z. L. Liu, Y. J. Liu, K. L. Yao, Z. H. Ding, J. Tao, X. Wang, J. Mater. Synth. Process. 10 (2002) 83-87.

[27] Y. Deng, D. Qi, C. Deng, X. Zhang, D. Zhao, J. Am. Chem. Soc. $130(2008)$ 28-29.

[28] K. Ahmadi, M. Ghaedi, A. Ansari. Spectrochim. Acta Part A136, 1441 (2015).

[29] M. Toor, B. Jin, S. Dai, V. Vimonses. J. Ind. Eng. Chem. 21, 653 (2015).

[30] H. Saygil1, F. Guzel. Chem. Eng. Res. Design 100, 27 (2015). 